\title{
Anguilla marmorata (Giant Mottled Eel) Discovered in a New Location: Natural Range Expansion or Recent Human Introduction? ${ }^{1}$
}

\author{
Alex Handler ${ }^{2}$ and Shelley A. Fames ${ }^{3}$
}

\begin{abstract}
Freshwater eels in the family Anguillidae spend a majority of their adult life in freshwater but migrate to the ocean to spawn and die. Because freshwater eels are believed to have a long larval period in the open ocean, it is unclear how the present global distribution of species arose. A stock of freshwater eels of the family Anguillidae was found on Palmyra Atoll in the central Pacific Ocean, in June 2003. In October 2003, a single eel specimen was caught using a hand net from this small group of eels on Palmyra Atoll. Morphological and molecular characters $(12 \mathrm{~S}$ and $16 \mathrm{~S}$ mitochondrial rRNA and cytochrome $\mathrm{b}$ mtDNA sequences) were used to identify the species as Anguilla marmorata Quoy \& Gaimard. The discovery of these eels on Palmyra supports the hypothesis of natural range expansion from the Indo-Pacific eastward to the Galápagos through the Line Islands, but further analysis of oceanic currents and more variable genes are required to assess whether humans are involved in the recent spread of Anguilla marmorata to these new locations.
\end{abstract}

Eels in the genus Anguilla Shaw, 1803 (family Anguillidae) have been a favored human food item since ancient Roman times (Smith 1989). Because of their commercial value, numerous Anguilla species have been introduced to locations outside their natural range to boost local eel populations. Recently, isolated individuals or populations of a number of species of Anguilla have been discovered in locations from which they were previously unknown (McDowall et al. 1998, McCosker et al. 2003). It is unclear whether eels arrived in these new locations with or without human assistance.

New range expansions of Anguilla species

${ }^{1}$ This work was funded by the NSF GK-12 grant DGE02-32016. Contribution No. 2004-019 to the Hawai'i Biological Survey. Manuscript accepted 14 February 2005.

${ }^{2}$ Center for Conservation Research and Training, Gilmore 409B, University of Hawai'i at Mānoa, 3050 Maile Way, Honolulu, Hawai'i 96822-2231 (e-mail: ahandler@hawaii.edu).

${ }^{3}$ Pacific Center for Molecular Biodiversity, Bishop Museum, 1525 Bernice Street, Honolulu, Hawai'i 96817 (e-mail: sajames@bishopmuseum.org).

Pacific Science (2006), vol. 60, no. 1:109-115

(C) 2006 by University of Hawai'i Press

All rights reserved have recently been documented in the $\mathrm{Pa}$ cific. McCosker et al. (2003) identified an eel caught in the Galápagos in 1998 as a species of Anguilla, most likely A. marmorata Quoy \& Gaimard, 1824. They hypothesized that the presence of freshwater eels in the Galápagos is a result of sporadic arrivals of larvae carried by ocean currents that pass through the Line Islands along the equator in the central Pacific. They argued that the eels had not been transported to the Galápagos by humans because they had been observed by island inhabitants long before air transportation could have enabled such transport. They did not address the possibility of live transport of eels by ship.

The East Australian longfinned eel, Anguilla reinhardtii Steindachner, 1867, has recently been reported in northern New Zealand (McDowall et al. 1998). Over eight consecutive years, new classes of this species have been recorded in the Waikato River, suggesting that recruitment is occurring on a regular basis (Chrisnall 1996, Jellyman et al. 1996). Commercial eel fishers have noticed "unusual eels in some northern [New Zealand] rivers for perhaps 25 years," but the formal identification only more recently of $A$. reinhardtii may have been because of its morphological similarity to New Zealand's endemic fresh- 


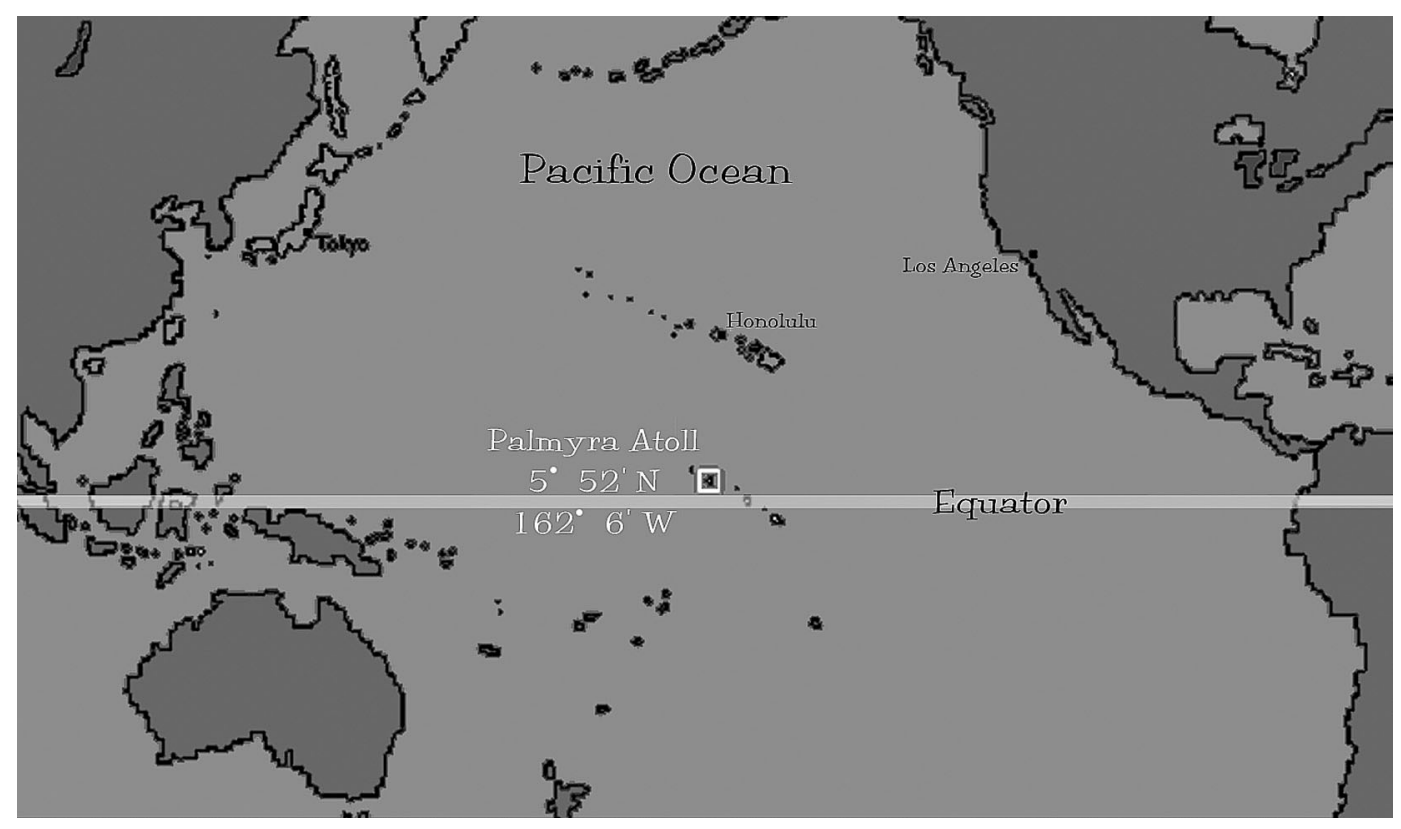

Figure 1. Palmyra Atoll, Line Islands.

water eel, A. diffenbachii Gray, 1846 (McDowall et al. 1998:1).

Anguillid eels spend a majority of their adult life in freshwater but migrate out to oceanic gyres to breed, spawn, and possibly die (Smith 1989). Anguillidae are a homogeneous group, relatively unspecialized morphologically and highly adaptable (Smith 1989). The single genus Anguilla consists of 15 species and three subspecies (Watanabe 2003). The evolutionary history of the Anguillidae and the origins of the current global distribution of species are still in question (Bastrop et al. 2000, Aoyama et al. 2001, Lin et al. 2001). They occur in all temperate and tropical waters except the southern Atlantic and the east coast of the Pacific (Aoyama et al. 2001). The larvae are transported away from spawning areas by oceanic currents (Bastrop et al. 2000).

Anguilla species have not been recorded previously on Palmyra Atoll, Line Islands (Figure 1). A stock of freshwater eels was discovered on Cooper Island, Palmyra Atoll, during a research trip in June 2003. In October 2003, a freshwater eel was caught from this small population on Cooper Island, Palmyra Atoll. Historically, morphological characters have been used to identify Anguilla species (Ege 1939). Recent molecular data suggest that identification based on morphological characters may not be reliable (Aoyama et al. 2001, Lin et al. 2001). Therefore, a combination of morphological and molecular characters was used to identify this specimen.

\section{MATERIALS AND METHODS}

A freshwater eel was collected on 13 October 2003 on Palmyra Atoll (Figure 2) from an artificial freshwater pond (former cesspool built between 1941 and 1947) on the southeast corner of Cooper Island, just off the airplane runway (GPS latitude/longitude: $05^{\circ} 53.42^{\prime}$ $\left.\mathrm{N}, 162^{\circ} 04.35^{\prime} \mathrm{W}\right)$. Morphological characters (Smith 1999) were used to obtain a preliminary identification of the specimen. Its identity was confirmed by molecular analysis.

A 427 base-pair fragment of the $12 \mathrm{~S}$ mitochondrial rRNA gene, a 628 base-pair fragment of the $16 \mathrm{~S}$ mitochondrial rRNA gene, 


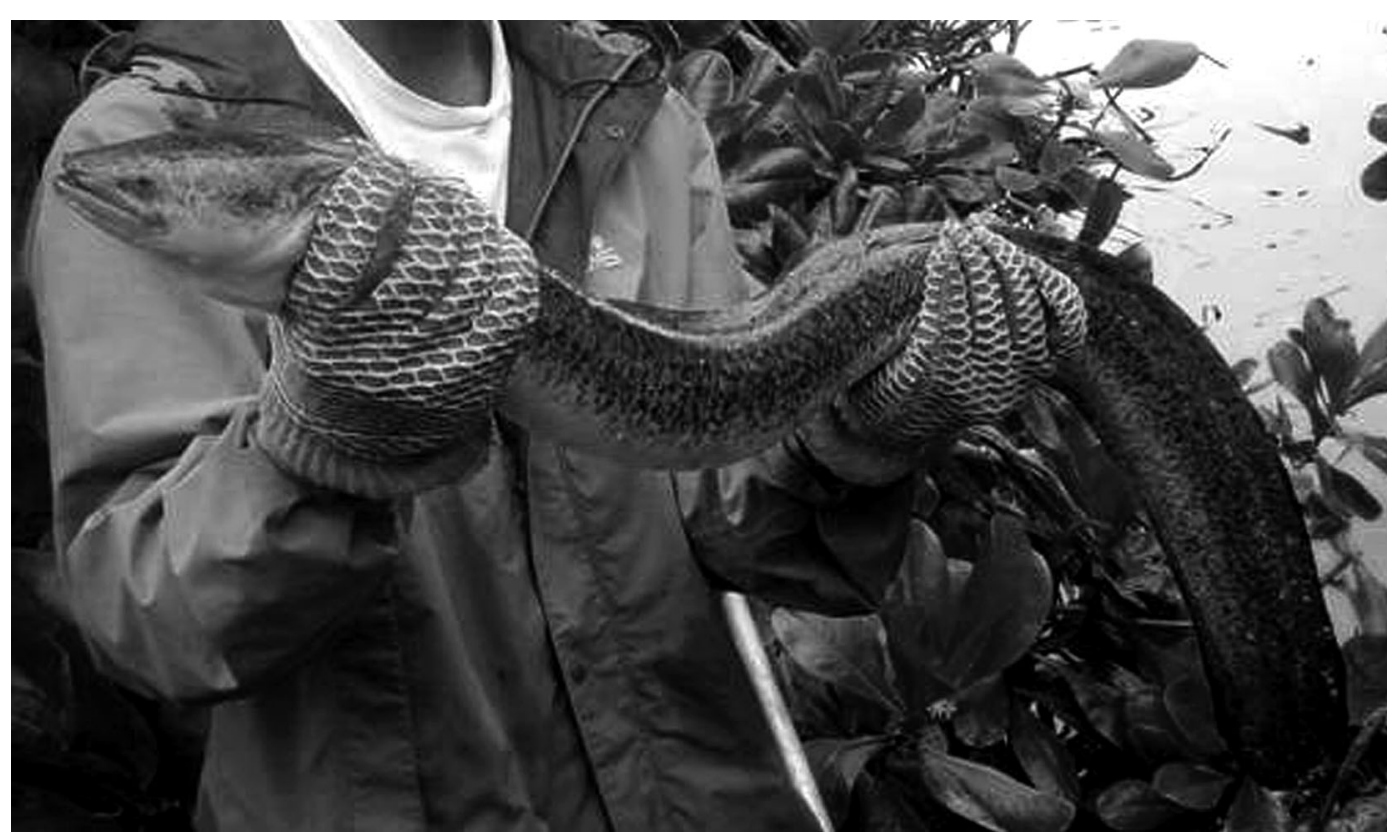

Figure 2. Freshwater eel (Anguilla marmorata) collected on 13 October 2003 on Palmyra Atoll.

and the complete mitochondrial cytochrome $\mathrm{b}$ gene were sequenced. Genomic DNA was extracted from muscle using the protocol of Sambrook and Russell (2001). Polymerase chain reaction (PCR) amplifications were performed in $50 \mathrm{ml}$ of a solution containing approximately $10 \mathrm{ng}$ of genomic DNA, 400 $\mathrm{mM}$ of each dNTP, 1.5 unit Taq Polymerase (Promega), $2 \mathrm{mM} \mathrm{MgCl}_{2}$, each primer at 1 $\mathrm{mM}$, and buffer. Primer sequences for the mitochondrial $12 \mathrm{~S}$ and $16 \mathrm{~S}$ genes were from Palumbi (1996) and for cytochrome b were from Aoyama et al. (2001) and Palumbi et al. (1991). PCR cycling parameters (PTC 100, MJ Research) for the initial double-stranded amplification were $94{ }^{\circ} \mathrm{C}$ for $1 \mathrm{~min}, 50{ }^{\circ} \mathrm{C}$ for $1 \mathrm{~min}$, and $72{ }^{\circ} \mathrm{C}$ for $1 \mathrm{~min}$, repeated for 45 cycles, with a final step of $72{ }^{\circ} \mathrm{C}$ for $5 \mathrm{~min}$. The PCR product was extracted using QIAQuick Gel Extraction Kit (Qiagen, Valencia, California) and visualized on an agarose gel. Cycle sequencing of 15-45 ng of the doublestranded PCR product was carried out with each primer and BigDye terminators (v. 3.1, ABI Biosystems) diluted to half concentration using $2.5 \times$ buffer. The sequences have been submitted to GenBank, under accession numbers AY735145-AY735147.

Paup 4.0b10 (Swofford 2002) and TreeRot.v2 (Sorenson 1999) were used to compare the cytochrome $b$ sequence of the Palmyra specimen with sequences of all other Anguilla species in GenBank as well as with all GenBank sequences of $A$. marmorata (the tentative identity of the specimen, based on morphological criteria) from other parts of its range. All characters were unordered and unweighted.

The specimen is deposited in the Bishop Museum ichthyology collection (врвм 39291) and voucher DNA is held at the Pacific Center for Molecular Biodiversity, Bishop $\mathrm{Mu}-$ seum (PCMB B313).

\section{RESULTS}

The specimen was identified as $A$. marmorata based on its mottled color and long dorsal fin, which differentiate it from other Anguilla species (Smith 1999). The 12S, 16S, and cytochrome b sequences confirmed the identification. The $12 \mathrm{~S}$ and $16 \mathrm{~S}$ sequences were 
identical to those of a specimen of $A$. marmorata from Kaupō on the south coast of Maui, Hawai'i, collected in 2002 (GenBank accession numbers AY207028 and AY207029, respectively). This specimen from Maui (врвм 39092) was identified as $A$. marmorata on the basis of morphology; its voucher DNA is also held in the Bishop Museum (PCMB B177). The 12S sequence of these two specimens was also identical to those of individuals from South Africa (GenBank accession number AF266485) and Indonesia (GenBank accession number AB021890), and one base pair different from an individual from Taiwan (GenBank accession number AF266484). The 16S sequences from the Maui and Palmyra individuals differed from that of the Indonesian individual by one base pair (GenBank accession number AB021760) and from those of four individuals from Taiwan from zero to three base-pair differences (GenBank accession numbers AJ244816, AJ244817, AJ244818, AJ244819).

Strong bootstrap support (100) and a decay index of 17 of the maximum parsimony tree derived from the cytochrome $b$ data support monophyly of $A$. marmorata (Figure 3). Maximum likelihood and distance-based (neighbor joining) trees based on the same data also support monophyly of $A$. marmorata (Maui Cytochrome b GenBank accession number AY738724). The other 14 species within the family Anguillidae served as outgroups for this particular test.

\section{DISCUSSION}

The discovery of a population of $A$. marmorata on Palmyra Atoll provides possible new insight into the spread of $A$. marmorata across the Pacific Ocean, as proposed by McCosker et al. (2003), who suggested that larvae could be transported in an easterly direction by either the Northern or Southern Equatorial Counter-Currents during El Niño/Southern Oscillation (ENSO) events. Although otolith data from the specimen collected in the Galápagos in 1997 (McCosker et al. 2003) do not support this hypothesis that the larva was transported during an ENSO event, it may still be possible that larvae arrived in the
Galápagos using the Equatorial CounterCurrents.

Multiple species of freshwater eels (A. anguilla, A. japonica, and $A$. rostrata) have been intentionally moved around the world for human consumption and the aquarium trade (Ringuet et al. 2002), suggesting that the eels discovered on Palmyra may have arrived there with the assistance of humans. Anguilla marmorata is not usually caught for consumption, but occasionally it is illegally caught and sold to restaurants (Lin et al. 2002). From the 1950 s to the 1960s, Anguilla species were imported into Hawai' $\mathrm{i}$, which is approximately $1,600 \mathrm{~km}$ north and slightly east of Palmyra, as live food and for the aquarium pet trade (A. Suzumoto, pers. comm.). Currently their import into Hawai' $i$ is prohibited.

An alternative hypothesis is that $A$. marmorata arrived in Palmyra naturally. There is a natural freshwater lake on Washington Island, just south and east of Palmyra. This lake has not been investigated for the presence of $A$. marmorata, but if it is present there, it may reflect expansion of its range from the western Indo-Pacific eastward through the Line Islands and then to Palmyra when habitat became available, and to the Galápagos, as proposed by McCosker et al. (2003).

Multiple studies have found that $A$. marmorata spawns along the western edge of the North Equatorial Current in the Pacific Ocean where the North Equatorial CounterCurrent splits from the North Equatorial Current and begins its flow eastward toward Palmyra Atoll (Arai et al. 2001a,b, Miller et al. 2002). One of these studies also found $A$. marmorata leptocephali in the westernmost edge of the South Equatorial Current and South Equatorial Counter-Current, where it begins flowing eastward through the Pacific Ocean (Arai et al. 2001a).

The fact that $A$. marmorata takes approximately 150 days to mature and migrate to a freshwater environment further supports the possibility that this species of eel has the capacity to travel long distances through the transport of the ocean currents mentioned here before having to move into a freshwater habitat to live (Arai et al. 2001b). Historical 


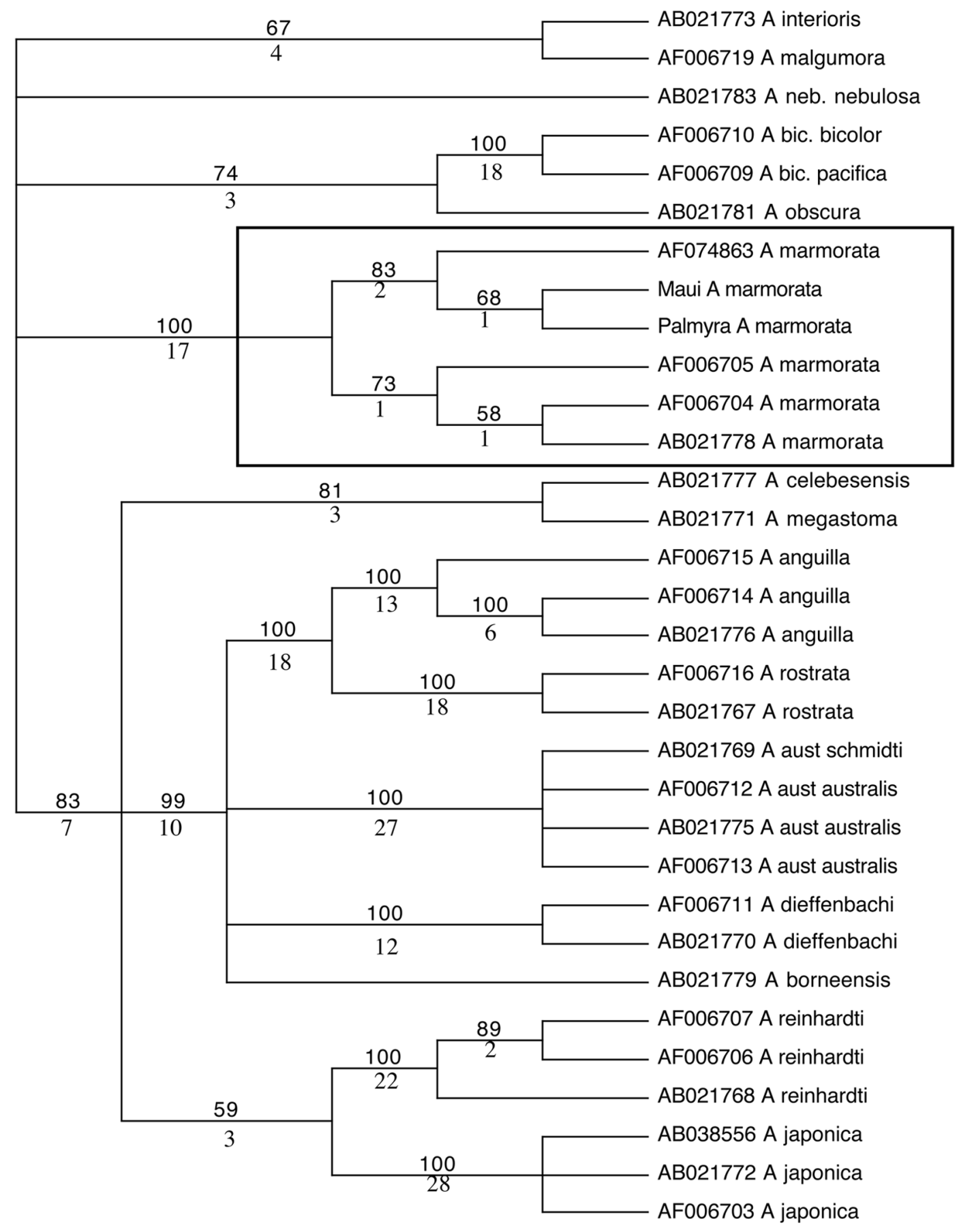

Figure 3. Maximum parsimony consensus tree of cytochrome b mtDNA of family Anguillidae with bootstrap values above branches and decay indices below (A. marmorata: AF074863, South Africa; AF006705, Taiwan; AF006704, Taiwan; AB021778, Indonesia). Note that Anguilla marmorata forms a monophyletic group. 
movements and range expansions of $A$. marmorata are complicated by the fact that this species has the widest distribution of any freshwater eel (Smith 1989). It exists in Madagascar and neighboring islands, Indonesia, the Philippines, Taiwan, and eastward through the western Pacific to the Marquesas. There is also a single record from South Africa (Smith 1989). Anguilliform fossils date back to the Cretaceous about 100 million yr ago (Bastrop et al. 2000).

This study did not permit a conclusive determination of the role humans have had in transporting $A$. marmorata to new locations in the central and western Pacific. Eels have begun to be noticed in new locations, possibly also a result of recent shifts in oceanic currents (McDowell et al. 1998, McCosker et al. 2003). Looking more closely at particular oceanic currents in the Pacific and determining if freshwater eels occur on Washington Island, combined with examining DNA sequences more appropriate for elucidating patterns at the population level (CO I or microsatellites), may help to determine whether A. marmorata dispersed naturally to Palmyra Atoll.

\section{ACKNOWLEDGMENTS}

We thank Kenneth Y. Kaneshiro for providing logistical support and funding for this project, Arnold Suzumoto for assisting with the preliminary species identification using morphological characters, Dan Rubinoff for sharing his evolutionary expertise, and Robert Cowie for his editorial comments.

\section{Literature Cited}

Aoyama, J., M. Nishida, and K. Tsukamoto. 2001. Molecular phylogeny and evolution of the freshwater eel, genus Anguilla. Mol. Phylogenet. Evol. 20:450-459.

Arai, T., J. Aoyama, S. Ishikawa, M. J. Miller, T. Otake, T. Inagaki, and K. Tsukamoto. 2001a. Early life history of tropical $A n$ guilla leptocephali in the western Pacific Ocean. Mar. Biol. (Berl.) 138:887-895.

Arai, T., D. Limbong, T. Otake, and K. Tsukamoto. 2001b. Recruitment mechanisms of tropical eels Anguilla spp. and implications for the evolution of oceanic migration in the genus Anguilla. Mar. Ecol. Prog. Ser. 216:253-264.

Bastrop, R., B. Stehlow, K. Jurss, and C. Sturmbauer. 2000. A new molecular phylogenetic hypothesis for the evolution of freshwater eels. Mol. Phylogenet. Evol. 14:250-258.

Chisnall, B. L. 1996. Aussie invasion. Seafood N.Z. 4 (7): 81.

Ege, V. 1939. A revision of the genus Anguilla Shaw: A systematic, phylogenetic and geographical study. Dana-Rep. Carlsberg Found. 16:1-256.

Jellyman, D. J., L. H. Dijkstra, B. W. Chisnall, and J. A. T. Boubee. 1996. The first record of the Australian longfinned eel, Anguilla reinbardtii, in New Zealand. Mar. Freshwater Res. 47:1037-1040.

Lin, Y., Y. Poh, and C. Tzeng. 2001. A phylogeny of freshwater eels inferred from mitochondrial genes. Mol. Phylogenet. Evol. 20:252-261.

Lin, Y., Y. Poh, S. Lin, and C. Tzeng. 2002. Molecular techniques to identify freshwater eels: RFLP analysis of PCRamplified DNA fragments and allelespecific PCF from mitochondrial DNA. Zool. Stud. 41:421-430.

McCosker, J. E., R. H. Bustamante, and G. M. Wellington. 2003. The freshwater eel, Anguilla marmorata, discovered in Galapagos. Not. Galapagos 62:2-6.

McDowall, R. M., D. J. Jellyman, and L. H. Dijkstra. 1998. Arrival of an Australian anguillid eel in New Zealand: An example of transoceanic dispersal. Environ. Biol. Fishes 51:1-6.

Miller, M. J., N. Mochioka, T. Otake, and K. Tsukamoto. 2002. Evidence of a spawning area of Anguilla marmorata in the western North Pacific. Mar. Biol. (Berl.) 140:809814.

Palumbi, S. R. 1996. Nucleic acids II: The polymerase chain reaction. Pages 205-247 in D. M. Hillis, C. Moritz, and B. K. Mable, eds. Molecular systematics. 2 nd ed. Sinauer Associates, Sunderland, Massachusetts.

Palumbi, A., S. Martin, S. Romano, W. O. McMillan, L. Stice, and G. Grabowski. 
1991. The simple fool's guide to PCR, version 2. University of Hawai'i at Mānoa, Honolulu.

Ringuet, S., F. Muto, and C. Raymakers. 2002. Eels: Their harvest and traffic. Traffic Bull. 19:80-106.

Sambrook, J., and D. W. Russell. 2001. Molecular cloning: A laboratory manual. 3rd ed. Cold Spring Harbor Laboratory Press, New York.

Smith, D. G. 1989. Family Anguillidae. Pages 25-47 in Fishes of the western North Atlantic, Part 9, Orders Anguilliformes and Saccopharungiformes. Sears Foundation for Marine Research, Yale Univ. Vol. 1.

. 1999. Family Anguillidae. Pages 1630-1636 in K. E. Carpenter and V. H.
Miem, eds. FAP species identification guide for fishery purposes. The living marine resources of the western central $\mathrm{Pa}$ cific. Batoid fishes, chimaeras and bony fishes Part 1 (Elopidae to Linophrynidae). Vol. 3. FAO, Rome.

Sorenson, M. D. 1999. TreeRot, version 2. Boston University, Boston, Massachusetts.

Swofford, D. L. 2002. Paup*. Phylogenetic analysis using parsimony (*and other methods). Version 4. Sinauer Associates, Sunderland, Massachusetts.

Watanabe, S. 2003. Taxonomy of the freshwater eels, Genus Anguilla Schrank, 1798. Pages 3-18 in K. Aida, K. Tsukamoto, and K. Yamauchi, eds. Eel biology. Springer-Verlag, Tokyo. 
